\title{
Isolation and Identification of Indigenous Bakers' Yeast
}

\author{
Nasrin Jahan, Nafisa Azmuda and Anisur Rahman Khan* \\ Department of Microbiology, University of Dhaka, Dhaka 1000, Bangladesh
}

[Received 13 April 2006; Accepted 21 April 2007]

\begin{abstract}
This investigation was performed to isolate and identify indigenous bakers' yeast. Initially, 75 yeast isolates were collected from different sources such as decomposed fruits, fermented rice and fermented fruit juices. Twenty five isolates were selected by primary screening; among them, ten isolates were considered as potential bakers' yeasts on the basis of their ability to produce high amount of biomass and leavening action. Two isolates were identified as Saccharomyces cerevisiae, seven as Saccharomyces species and only one as Kluyveromyces species. These isolates have sufficient potential to be produced commercially after evaluation of some baking parameters like texture and organoleptic properties.
\end{abstract}

Keywords: Bakers’ yeast, Saccharomyces cerevisiae, Cell mass, Leavening action

Yeasts are of great economic importance. Yeasts, especially different strains of Saccharomyces cerevisiae have long been used for the production of alcoholic beverages, solvents and other chemicals ${ }^{1}$. In the modern bakery, yeasts are used for manufacturing of different kinds of bread and confectinaries ${ }^{2}$. It is responsible for leavening the dough and imparting a delicious flavour to the product. Yeast converts the fermentable sugars present in the dough into carbon dioxide ${ }^{3-4}$. This causes the dough to expand or rise as the carbon dioxide forms pockets or bubbles. When the dough is baked it 'sets' and the pockets remain, giving the baked product a soft and spongy texture. The aroma of bread is created during baking by thermal reactions within some of its individual components formed by yeast fermentation and between these compounds and other dough constituents such as some amino acids ${ }^{4-5}$. When there is an excess of amino acids, they are degraded to aromatic carbonyl compounds ${ }^{6}$. In addition, yeast is a valuable source of protein and vitamins, especially certain amino acids like lysine, methionine and threonine and B-group vitamins $^{5,7}$. Hence, many bakery products are currently being prepared with the addition of inactive dried yeasts ${ }^{5-9}$.

Most of the baking industries of Bangladesh use baking powder (mixture of $\mathrm{NaHCO}_{3}$, potassium hydrogen tartarate). In recent years, the use of bakers' yeast has increased in bread making in our bakery industries. Its use is expensive than chemical because bakers' yeasts are not produced in our country. It is being imported in huge amount every year for baking purpose. Since in the recent years, growing concern in making quality bread, the import size has gradually been increased. So, a considerable amount of foreign currency has to be spent for this purpose. Therefore, exploitation of indigenous yeast is very important, and for this reason, an attempt was made to isolate and identify indigenous bakers' yeast in this study.
Malt extract yeast extract glucose peptone (MYGP) medium ${ }^{10}$, urease test broth, bromocresol purple broth, nitrate broth, yeast extract agar media and actidione agar media ${ }^{11}$ were used to isolate and identify indigenous yeast isolates. Indigenous yeasts were isolated from different decomposed fruits such as mango, banana peel, apple, grape, lichi, black berry, date fruit, jack fruit, orange, pine apples as well as fermented sugar cane juice and fermented rice. The isolation and identification of yeasts were carried out as described by Perkins ${ }^{12}$. Biomass mass production was carried out according to standard procedure ${ }^{13}$. Dough was prepared by mixing $0.5 \mathrm{~g}$ yeast cells, $50 \mathrm{~g}$ wheat flour, $4.0 \mathrm{~g}$ sugar, $1.0 \mathrm{~g}$ salt, 10 $\mathrm{ml}$ fresh milk, $1 \mathrm{ml}$ soybean oil, 1 tea spoon of egg, 1 tea spoon of butter and $60 \mathrm{ml}$ water. All the ingredients were homogeneously mixed and incubated at $30^{\circ} \mathrm{C}$ for fermentation. The dough volume was recorded at every $60 \mathrm{~min}$ interval. The initial and final dough volumes were recorded from the graduated surface of the beaker and the net increased volume was calculated according to the standard procedure ${ }^{13}$.

Initially, 75 yeast isolates were recovered from various sources. Among them 25 potential isolates were screened out on the basis of cell mass production and leavening action. Table 1 represents the results of cell mass production and leavening action of 25 selected yeast isolates. The cell mass production ranged from 9 to $24 \mathrm{mg} / \mathrm{ml}$. Among the isolates, FSC-1, FSC-2, DP-2, DP-4, DG-4, DG-6, FR-1, DM-1, DB-1 and DA-2 exhibited relatively higher cell mass yield ranging from 13 to $24 \mathrm{mg} / \mathrm{ml}$. These isolates were then used to check their leavening action. The leavening action of these ten isolates was found to be superior to the remaining other isolates that showed 80.00 to $105.00 \%$ increase of dough volume after fermentation. These indigenous isolates were considered as potential for baking purposes. Nine isolates, namely, FSC-1,

*Corresponding author:

Dr. M Anisur Rahman Khan, Professor \& Chairman, Department of Microbiology, University of Dhaka, Dhaka 1000, Bangladesh

Tel (Office): (02) 9991920-73/7730, 7740; Tel (Home): (02) 9571211; Cell: 01199 156618; Fax: +880 (02) 8615583; E-mail: anis37@yahoo.com 
FSC-2, DP-2, DP-4, DG-4, DG-6, DB-1, FR-1 and DM-1 were identified as Saccharomyces sp. and among them FR-1 and DM-1 were identified as Saccharomyces cerevisiae (Table 1). Only one isolate, DA-2, was identified as Kluyveromyces sp.

Table 1. Cell mass production and leavening action of some indigenous yeast isolates

\begin{tabular}{|c|c|c|c|c|c|}
\hline \multirow[t]{2}{*}{ Yeast isolate } & \multirow[t]{2}{*}{$\begin{array}{c}\text { Cell mass } \\
(\mathrm{mg} / \mathrm{ml})\end{array}$} & \multicolumn{2}{|c|}{$\begin{array}{c}\text { Leavening } \\
\text { volume }\left(\mathrm{cm}^{3}\right)\end{array}$} & \multirow{2}{*}{$\begin{array}{c}\text { Volume } \\
\text { increase } \\
(\%)\end{array}$} & \multirow{2}{*}{$\begin{array}{c}\text { Time } \\
\text { required } \\
\text { (h) }\end{array}$} \\
\hline & & Initial & Final & & \\
\hline Unidentified DA-1 & 19.66 & 86.23 & 165.83 & 92.30 & 13 \\
\hline Kluyveromyces sp. DA-2 & 14.94 & 76.28 & 149.25 & 95.65 & 13 \\
\hline Saccharomyces sp. DB-1 & 19.96 & 79.60 & 155.88 & 95.83 & 13 \\
\hline Unidentified DB-2 & 12.19 & 59.70 & 106.13 & 77.78 & 13 \\
\hline Unidentified DB-3 & 19.78 & 89.55 & 155.88 & 74.07 & 13 \\
\hline Unidentified DG-1 & 22.24 & 89.55 & 155.88 & 74.07 & 13 \\
\hline Unidentified DG-2 & 21.22 & 73.00 & 145.93 & 100.00 & 23 \\
\hline Unidentified DG-3 & 24.01 & 86.23 & 159.20 & 84.61 & 23 \\
\hline Saccharomyces sp. DG-4 & 16.13 & 76.28 & 155.88 & 104.35 & 13 \\
\hline Unidentified DG-5 & 23.32 & 86.23 & 155.88 & 80.77 & 13 \\
\hline Saccharomyces sp. DG-6 & 24.15 & 66.33 & 135.982 & 105.00 & 13 \\
\hline S. cerevisiae DM-1 & 9.94 & 99.50 & 199.00 & 100.00 & 13 \\
\hline Unidentified DM-2 & 10.32 & 86.23 & 106.13 & 23.08 & 13 \\
\hline Unidentified DP-1 & 22.43 & 82.92 & 139.30 & 68.00 & 23 \\
\hline Saccharomyces sp. DP-2 & 24.45 & 82.92 & 149.25 & 78.00 & 13 \\
\hline Unidentified DP-3 & 11.89 & 69.65 & 155.88 & 123.81 & 13 \\
\hline Saccharomyces sp. DP-4 & 13.45 & 82.92 & 159.20 & 92.00 & 7 \\
\hline S. cerevisiae FR-1 & 16.96 & 99.50 & 202.31 & 102.81 & 4 \\
\hline Unidentified FR-2 & 17.68 & 86.23 & 155.88 & 80.77 & 23 \\
\hline Saccharomyces sp. FSC-1 & 17.68 & 82.92 & 149.25 & 80.00 & 13 \\
\hline Saccharomyces sp. FSC-2 & 13.69 & 79.60 & 165.83 & 109.00 & 13 \\
\hline Unidentified FSC-3 & 22.24 & 82.92 & 149.25 & 80.00 & 23 \\
\hline Unidentified FSC-4 & 14.94 & 89.55 & 155.88 & 74.07 & 23 \\
\hline Unidentified FSC-5 & 24.01 & 82.92 & 139.30 & 68.00 & 23 \\
\hline Unidentified FSC-6 & 10.32 & 59.70 & 106.13 & 77.78 & 23 \\
\hline
\end{tabular}

Indigenous selected bakers' yeasts exhibited excellent leavening capacity. Organisms were fast growing and produced appreciable amount of biomass within short period. Yeast biomass is quite a complete additive $^{6}$ that can fortify a diet with different nutritional components as well as proteins $s^{6,9,14-15}$. As an excellent food additive, yeast would contribute polyunsaturated fatty acids, different vitamins, glutathione, and, above all, lysine-, methionineand threonine-rich proteins to the $\operatorname{diet}^{3-4,6}$.
The present study showed that some indigenous yeast isolates could be considered as potential sources of bakers' yeasts considering the biomass yield and leavening action. However, dough fermented with indigenous bakers' yeasts should be evaluated for bakery products with respect to texture taste and aroma. In addition, bread content of the essential amino acids lysine, methionine and threonine should be evaluated and pilot plant scale study for mass production of the isolates should be carried out in future for their industrial use.

\section{References}

1. Lyall N. 1970. Studies on the ecology of yeasts. Baking Ind J. 3: 4852.

2. Reed G. 1982. Production of bakers' yeast. In Prescott and Dunn's Industrial Microbiology (Reed G ed), $4^{\text {th }}$ edn, pp 593-627. AVI Publishing Co Inc, Westport, Connecticut.

3. Oda Y \& Ouchi K. 1990. Hybridization of bakers' yeast by the raremating method to improve leavening ability in dough. Enzyme Microb Technol. 12: 989-993.

4. Oda Y \& Ouchi K. 1991. Construction of a sucrose-fermenting bakers' yeast incapable of hydrolysing fructooligosaccharides. Enzyme Microb Technol. 13: 495-498.

5. Kamel BS \& Stauffer CE. 1993. Advances in Baking Technology. Blackie Academic and Professional, London.

6. Rhem HJ \& Reed G. 1996. Biotechnology, Vol 9: Enzymes, Biomass, Food and Feed. VCH, Weinheim.

7. Burrows S. 1979. Bakers’ yeast. Econ Microbiol. 4: 31-64.

8. Bený tez T, Gasent-Ramý'rez JM, Castrejón F \& Codón AC. 1996. Development of new strains for the food industry. Biotechnol Prog. 12: $149-163$.

9. Ra'ndez-Gil F, Sanz P \& Prieto JA. 1999. Engineering bakers' yeast: Room for improvement. Trends Biotechnol. 17: 237-244.

10. Mot RD, Dijk KV, Donkers A \& Verachtert H. 1985. Potentialities and limitations of direct alcoholic fermentation of starchy materials with amylolactic yeasts. Appl Microbiol. 22: 222-226.

11. Barnett JA, Payne RW \& Yarrow D. 1983. In Yeasts Characteristics and Identification, pp 1-35. Cambridge University Press, Cambridge.

12. Perkins JJ. 1976. In Principles and Methods of Sterilization in Health Science, pp 286-292. Charles C Thomas Publishers, Springfield III.

13. Perveen M. 1991. Isolation, characterization and evaluation of indigenous bakers' yeast, pp. 18-21. MSc Thesis. Department of Microbiology, University of Dhaka, Dhaka.

14. Randez-Gil F \& Sanz P. 1994. Construction of industrial bakers' yeast strains able to assimilate maltose under catabolite repression conditions. Appl Microbiol Biotechnol. 42: 581-586.

15. Randez-Gil F, Blasco A, Prieto JA \& Sanz P. DOGR1 and DOGR2: Two genes from Saccharomyces cerevisiae that confer 2-deoxyglucose resistance when overexpressed. Yeast. 11: 1233-1240. 